\title{
PENGARUH MODEL PEMBELAJARAN INKUIRI TERHADAP HASIL BELAJAR SISWA PADA MATERI POKOK GERAK LURUS DI KELAS X SMASWASTA HARAPAN BANGSA KUALA T.P. 2014/2015
}

\author{
Aswitha Sari dan Betty M. Turnip \\ Jurusan Fisika FMIPA Universitas Negeri Medan \\ Jalan Willem Iskandar Pasar V Medan \\ aswitha_sari@gmail.com
}

\begin{abstract}
ABSTRAK
Penelitian ini bertujuan untuk mengetahui pengaruh model pembelajaran Inkuiri terhadap hasil belajar pada materi gerak lurus di kelas X SMA Swasta Harapan Bangsa Kuala T.P. 2014/2015. Jenis penelitian ini adalah quasi eksperimen dengan populasi seluruh siswa kelas X SMA Swasta Harapan Bangsa yang terdiri dari 2 kelas. Sampel penelitian diambil 2 kelas yang ditentukan dengan teknik cluster random sampling, yaitu kelas X-1 dengan menggunakan model pembelajaran inkuiri dan kelas X-2 dengan pembelajaran konvensional. Instrumen yang digunakan dalam penelitian ini terdiri dari: (1) tes hasil belajar kognitif dalam bentuk pilihan berganda dengan 5 option sebanyak 20 soal, (2) lembar observasi afektif siswa, dan (3) lembar observasi psikomotorik siswa. Analisa data menunjukkan nilai rata-rata pretes kelas eksperimen 27,97 dan kelas kontrol 29,83. Hasil analisis data pretes menunjukkan bahwa sampel berasal dari populasi yang berdistribusi normal, varians kedua sampel homogen, dan kedua sampel memiliki kemampuan awal yang sama. Setelah dilakukan perlakuan dan sekaligus mengobservasi afektif dan psikomotorik diperoleh nilai rata-rata postes pada kelas eksperimen dan kelas kontrol masing-masing 72,50 dan 65,67. Berdasarkan hasil analisis data postes menggunakan uji-t diperoleh bahwa ada pengaruh model pembelajaran Inkuiri terhadap hasil belajar siswa pada pada materi pokok gerak lurus di kelas X SMA Swasta Harapan Bangsa Kuala T.P 2014/2015. Model pembelajaran inkuiri dapat digunakan sebagai salah satu alternatif model pembelajaran dalam upaya meningkatkan hasil belajar siswa.
\end{abstract}

Kata Kunci : model pembelajaran inkuiri, hasil belajar, gerak lurus.

\section{PENDAHULUAN}

Salah satu masalah pokok dalam pembelajaran pada pendidikan formal (sekolah) dewasa ini adalah masih rendahnya daya serap siswa. Kemudian kekurang nyamanan siswa serta kurangnya motivasi belajar siswa saat proses belajar mengajar berlangsung. Hal ini nampak dari realita hasil belajar siswa yang senantiasa masih sangat memprihatinkan.

Rendahnya hasil belajar fisika siswa ini juga disebabkan karena 
beberapa hal diantaranya karena pembelajaran yang pada umumnya dilakukan secara teacher-centered sehingga siswa menjadi pasif dan saat guru memberi pelajaran, siswa hanya terfokus kepada guru, mereka tidak belajar secara partisipasif, aktif, kreatif dan efektif.

Berdasarkan hasil pengalaman peneliti pada saat pelaksanaan PPLT di SMA Swasta Harapan Bangsa Kuala menyatakan bahwa hasil belajar Fisika siswa rendah. Hal ini terlihat dari minat ataupun gairah siswa untuk belajar Fisika hampir tidak ada. Sebagian dari para siswa ada yang terlihat mengantuk, menguap dan siswa yang tidak mengantuk terlihat bingung dengan mengkerutkan dahi melihat gurunya menjelaskan materi. Bahkan setiap memasuki jam pelajaran Fisika, ada saja beberapa siswa yang bolos. Hal ini didukung dari nilai Ujian Tengan Semester I di kelas X1 dan di kelas $\mathrm{X} 2$ hanya $20 \%$ siswa yang mencapai kriteria ketuntasan Minimal (65).

Hasil wawancara yang dilakukan peneliti kepada seorang guru Fisika mengungkapkan bahwa hal yang membuat hasil belajar siswa rendah adalah kurangnya minat siswa dalam belajar Fisika. Hal ini disebabkan oleh proses pembelajaran di kelas selama ini cenderung masih menggunakan pembelajaran konvensional dengan kata lain kegiatan pembelajaran berpusat pada guru sehingga siswa cenderung pasif dan malas untuk berpikir. Selain itu, dengan teori-teori yang dijelaskan oleh guru tanpa adanya aplikasi dan juga kegiatan praktikum membuat siswa semakin jenuh.

Selain itu, peneliti juga membagikan angket kepada siswa untuk mengetahui sejauh mana minat para siswa terhadap mata pelajaran fisika. Dari hasil angket menyatakan bahwa hanya 7 dari 49 siswa yang menyenangi pelajaran fisika. Hal tersebut terjadi karena siswa mengalami kesulitan dalam memahami rumus dan konsep dari materi yang diberikan.

Menurut Trianto, (2011:165)

menyatakan, bahwa suatu pembelajaran pada umumnya akan lebih efektif bila diselenggarakan melalui model-model pembelajaran yang termsuk rumpun pemrosesan informasi. Hal ini dikarenakan model-model pemrosesan informasi menekankan pada bagaimana seseorang berpikir dan bagaimana dampaknya terhadap cara-cara mengolah informasi. Oleh karena itu guru dituntut menggunakan model pembelajaran yang bervariasi dan disesuaikan dengan kondisi ataupun situasi belajar agar motivasi serta minat siswa untuk belajar tetap tinggi dan semangat dalam mengajar hingga akhirnya tujuan belajar dapat tercapai dengan efektif dan efisien, cepat dan tepat. Salah satu usaha yang dilakukan peneliti untuk meningkatkan hasil belajar siswa adalah menerapkan model pembelajaran Inkuiri yang diharapkan mampu meningkatkan hasil belajar fisika siswa.

Inkuiri yang dalam bahasa Inggris inquiry, berarti pertanyaan, atau pemeriksaan, penyelidikan. Inkuiri sebagai suatu proses umum yang dilakukan manusia untuk mencari atau memahami informasi. Menurut (Sani, 2013:94) siswa dilatih untuk mengembangkan dan menggunakan keterampilan berpikir kritis, mulai dari membuat referensi, menyimpulkan, menghitung, mengidentifikasikan hubungan, 
menerapkan konsep, dan membuat perbandingan.

Trianto

(2011:168)

menyatakan, bahwa inkuiri tidak hanya mengembangkan kemampuan intelektual tetapi seluruh potensi yang ada, termasuk pengembangan emosional dan keterampilan inkuiri merupakan suatu proses yang bermula dari merumuskan masalah, merumuskan hipotesis, mengumpulkan data, menganalisis data, dan membuat kesimpulan.

Menurut (Eggen dan Kauchak, 2012:328) Model Pembelajaran Inkuiri memiliki empat tahap pembelajaran yaitu : Fase $I$ : Mengidentifikasi Pertanyaan. Guru atau (idealnya) murid mengidentifikasi satu pertanyaan yang akan coba dijawab oleh siswa. Fase II : Membuat Hipotesis. Siswa membuat hipotesis yang berusaha menjawab pertanyaan. Fase III : mengumpulkan dan menganalisis data. Siswa mengumpulkan data terkait dengan hipotesis dan menyususn serta menampilkannya supaya data itu bisa dianalisa. Fase $I V$ : menilai hipotesis dan membuat generalisasi. Guru memandu diskusi tentang hasil dan sejauh mana hasilhasil itu mendukung hipotesis. Juga, murid melakukan generalisasi terhadap hasil berdasarkan asesmen terhadap hipotesis.

Tujuan penelitian ini adalah untuk (1) mengetahui hasil belajar siswa menggunakan model pembelajaran inkuiri dan pembelajaran konvensional pada materi Gerak Lurus di kelas X SMA Swasta Harapan Bangsa Kuala T.P 2014/2015, (2) mengetahui afektif dan psikomotorik siswa menggunakan model pembelajaran inkuiri dan pembelajaran konvensional pada materi Gerak Lurus di kelas X SMA Swasta Harapan Bangsa Kuala T.P 2014/2015, (3) mengetahui pengaruh model pembelajaran inkuiri terhadap hasil belajar siswa pada materi pokok Gerak Lurus kelas X SMA Swasta Harapan Bangsa Kuala T.P 2014/2015

\section{METODE PENELITIAN}

Penelitian ini dilaksanakan di SMA Swasta Harapan Bangsa Kuala dengan alamat Jl. Binjai Km. 18,5 Pasar 1 Kuala pada materi pokok Gerak Lurus Tahun Pembelajaran 2014/2015. Sampel dalam penelitian ini terdiri dari dua kelas, yaitu kelas X-1 dan kelas X-2 yang diambil dengan teknik cluster random sampling. Penelitian ini termasuk jenis penelitian quasi eksperimen,. Untuk mengetahui hasil belajar, siswa diberikan tes. Tes yang dilakukan yaitu pretes (sebelum diberi perlakuan) dan postes (setelah diberi perlakuan). Desain penelitiannya berupa Control group pre-test-post-test seperti ditunjukkan pada Tabel 1.

Tabel 1. Desain penelitian Control

\begin{tabular}{|c|c|c|c|}
\hline $\mathrm{E}$ & & & \\
\hline $\mathrm{K}$ & $\mathrm{O}_{3}$ & X & \\
\hline
\end{tabular}

Keterangan :

$\mathrm{X}=$ Pengajaran dengan menerapkan model pembelajaran inkuiri (kelas eksperimen) dan pembelajaran konvensional (kelas kontrol).

$0_{1}=$ Pretes pada kelas eksperimen

$0_{2}=$ Postes pada kelas eksperimen

$0_{3}=$ Pretes pada kelas kontrol

$0_{4}=$ Postes pada kelas kontrol 
Data yang diperoleh diuji normalitasnya untuk mengetahui apakah data kedua sampel berdistribusi normal atau tidak. Uji normalitas data digunakan uji Lilliefors. Kemudian dilakukan uji homogenitas berfungsi untuk mengetahui apakah kedua sampel berasal dari populasi yang homogen. Menurut Sudjana (2005:249), untuk uji homogenitas data populasi digunakan uji kesamaan varians. Untuk Uji Hipotesis digunakan uji t dengan rumus :

$$
t=\frac{\bar{x}_{1}-\bar{x}_{2}}{S \sqrt{\frac{1}{n_{1}}+\frac{1}{n_{2}}}} \quad \text { Sudjana, 2005:239) }
$$

Kriteria pengujian adalah Ho diterima jika $\quad-t_{\left(1-1 / 2^{\alpha}\right)}<t<t_{(1-1 / 2 \alpha)}$ dimana $t_{\left(1-\frac{1}{2} \alpha\right)}$ didapat dari daftar distribusi $\mathrm{t}$ dengan $d k=n_{1}+n_{2}-2$ dan peluang $\left(1-\frac{1}{2} \alpha\right) . H_{a}$ diterima jika thitung $>t_{\text {tabel }}\left(t_{\text {tabel }}\right.$ diperoleh dari daftar distribusi t untuk $a=0,05$ ). Harga t lainnya Ho ditolak.

Untuk mengetahui afektif dan psikomotorik siswa diperoleh pada saat diberikan perlakuan atau pada saat proses pembelajaran berlangsung. Teknik analisis hasil belajar afektif dan psikomotorik siswa adalah sama, yaitu (1) Mentabulasi data, (2) Menghitung skor dan nilai, (3) Menghitung ratarata skor dan nilai setiap pertemuan, (4) Menyimpulkan hasil belajar setiap siswa, (5) Membuat distribusi hasil belajar, (6) Membuat diagram dan grafik perkembangan hasil belajar, (7) Membuat diagram pencapaian indikator hasil belajar.

\section{HASIL PENELITIAN DAN PEMBAHASAN}

\section{Hasil Penelitian}

Hasil belajar yang didapat selama selama penelitian ada tiga bentuk yaitu hasil belajar sebelum diberikan perlakuan yang disebut dengan pretes, kemudian hasil belajar selama proses perlakuan berlangsung yaitu hasil belajar afektif dan psikomotorik dan yang terakhir hasil belajar setelah diberikan perlakuan yang disebut dengan postes.

\section{Pretes}

Berdasarkan hasil tes yang telah dilakukan di SMA Swasta Harapan Bangsa Kuala diperoleh data mengenai hasil belajar siswa untuk kelas eksperimen dan kelas kontrol. Adapun data hasil belajar pretes kelas kontrol dan eksperimen dapat dilihat pada Gambar 1.

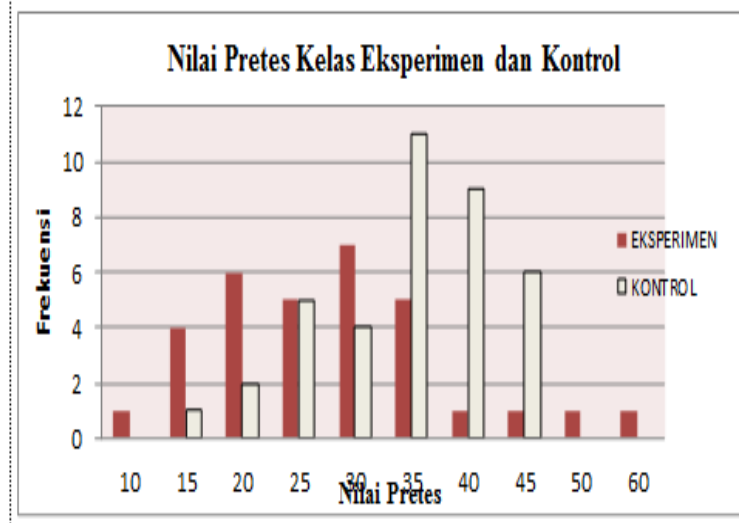

Gambar 1. Diagram Batang Nilai Pretes Kelas Eksperimen dan Kelas Kontrol

Sebelum pengujian hipotesis dilakukan, maka sampel penelitian harus memenuhi beberapa persyaratan yang harus dipenuhi yaitu sampel berasal dari populasi yang berdistribusi normal. Pengujian 
normalitas dilakukan dengan menggunakan uji Lilliefors, dan dari hasil pengujian diperoleh hasil seperti yang tertera pada Tabel 2 .

Tabel 2. Ringkasan Perhitungan Uji Normalitas

\begin{tabular}{|l|c|c|c|}
\hline \multicolumn{1}{|c|}{ Kelas } & $\mathrm{L}_{\text {hitung }}$ & $\mathrm{L}_{\text {tabel }}$ & Kesimpulan \\
\hline Eksperimen & 0,1489 & 0,1565 & Berdistribusi Normal \\
\hline Kontrol & 0,1587 & 0,1610 & Berdistribusi Normal \\
& & & \\
\hline
\end{tabular}

Berdasarkan Tabel 2 didapat bahwa Lhitung $^{<} \mathrm{L}_{\text {tabel }}$ sehingga dapat disimpulkan bahwa sampel berasal dari populasi yang berdistribusi normal.

Pengujian homogenitas dilakukan untuk mengetahui apakah sampel yang digunakan dalam penelitian ini berasal dari populasi yang homogen atau tidak. Hasil pengujian diperoleh seperti pada Tabel 3.

Tabel 3. Ringkasan Perhitungan Uji Homogenitas

\begin{tabular}{|c|c|l|l|l|l|}
\hline Data & Kelas & Varians $\left(S^{2}\right)$ & $\mathrm{F}_{\text {lutum }}$ & $\mathrm{F}_{\text {tabel }}$ & Keterangan: \\
\hline \multirow{2}{*}{ Pretes } & Eksperimen & 85,26 & \multirow{2}{*}{1,22} & \multirow{2}{*}{1,83} & \multirow{2}{*}{ Homogen } \\
\cline { 2 - 3 } & Kontrol & 69,79 & & & \\
\hline
\end{tabular}

Berdasarkan Tabel 3 dapat dilihat nilai $\mathrm{F}_{\text {hitung }}<\mathrm{F}_{\text {tabel }}$ yang berarti bahwa sampel yang digunakan dalam penelitian ini dinyatakan homogen atau dapat mewakili seluruh populasi yang ada.

Setelah sampel memenuhi persyaratan normalitas dan homogenitas maka dilakukan pengujian hipotesis. Dalam penelitian ini menggunakan uji beda (uji t). Dari hasil pemberian pretes kepada kelas eksperimen diperoleh nilai rata-rata 27,97 dan hasil pemberian pretes kepada kelas kontrol diperoleh nilai rata-rata 29,83 .

Ringkasan perhitungan uji hipotesis kelas eksperimen dan kelas kontrol dapat dilihat pada Tabel 4 .

Tabel 4. Ringkasan Perhitungan Uji Hipotesis

\begin{tabular}{|l|c|c|c|c|}
\hline \multicolumn{1}{|c|}{ Data Kelas } & $\begin{array}{c}\text { Nilai } \\
\text { Rata - rata }\end{array}$ & $t_{\text {hituns }}$ & $t_{\text {tabol }}$ & Kesimpulan \\
\hline Pretes Eksperimen & 27,97 & \multirow{2}{*}{0,91} & 2,00 & Terima Ho \\
\hline Pretes Kontrol & 29,83 & & \\
\hline
\end{tabular}

Berdasarkan Tabel 4, hasil perhitungan uji perbedaan nilai ratarata pretes kelas eksperimen dan kelas kontrol untuk $\alpha=0,05$ diperoleh $t_{\text {hitung }}=0,91$ dan $\mathrm{t}_{\text {tabel }}=$ 2,00 , maka $-t_{\text {tab }}<t_{\text {hit }}<t_{\text {tab }}$ atau $-0,91<$ $2,00<0,91$, berarti $\mathrm{H}_{0}$ diterima, sehingga dapat disimpulkan bahwa kemampuan awal siswa pada kelas eksperimen sama dengan kemampuan awal siswa pada kelas kontrol sebelum diberikan perlakuan.

\section{Hasil Belajar Selama Proses Perlakuan}

a. Hasil Belajar Afektif

Hasil penelitian menunjukkan bahwa hasil belajar siswa di bidang afektif di kelas eksperimen adalah sebesar 74,87. Sedangkan di kelas kontrol dengan nilai rata-rata sebesar 65,97 yang mana nilai sikap dari masing-masing kelas berkategori tinggi Hal ini sesuai dengan diagram seperti Gambar 2. 


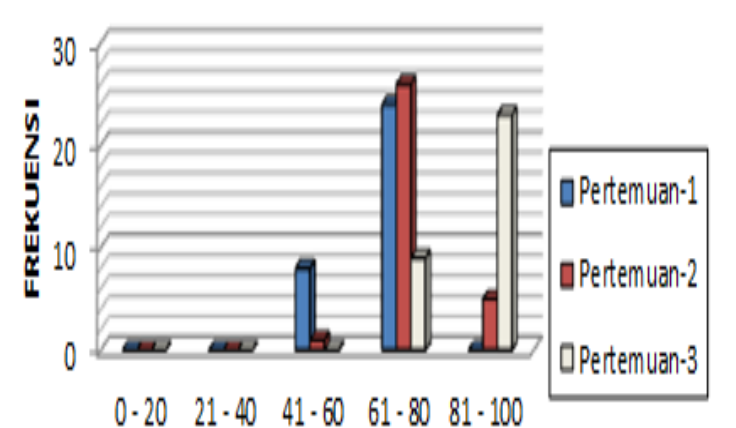

NILAI

Gambar 2. Diagram batang hasil belajar afektif kelas eksperimen

Berdasarkan Gambar 2 dapat dilihat bahwa terjadi perubahan pada hasil belajar afektif siswa. Perubahan tersebut diperoleh selama menerima pelajaran dengan model pembelajaran inkuiri.

Hasil belajar afektif di kelas kontrol dapat juga dilihat diagram batang pada Gambar 3 .

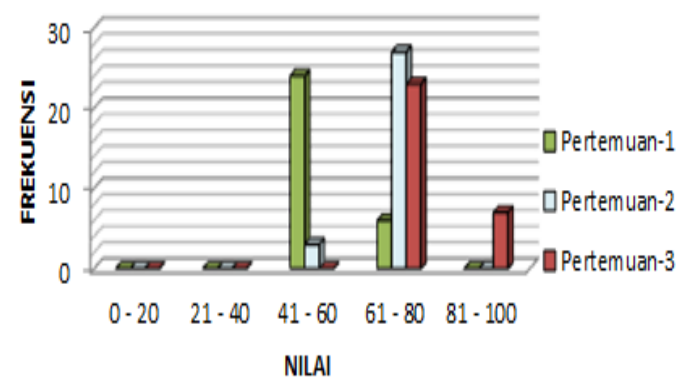

Gambar 3. Diagram batang hasil belajar afektif kelas kontrol

Berdasarkan Gambar 3 dapat dilihat bahwa terjadi perubahan pada hasil belajar afektif siswa. Perubahan tersebut sebagai hasil belajar yang diperoleh selama menerima pelajaran dengan pembelajaran konvensional.

\section{b. Hasil Belajar Psikomotorik}

Hasil penelitian menunjukkan bahwa hasil belajar siswa di bidang psikomotorik di kelas eksperimen adalah sebesar 64,58 dengan kategori baik. Sedangkan di kelas kontrol dengan nilai rata-rata sebesar 49,26 dengan kategori cukup. Hal ini sesuai dengan diagram seperti ditunjukkan pada Gambar 4 .

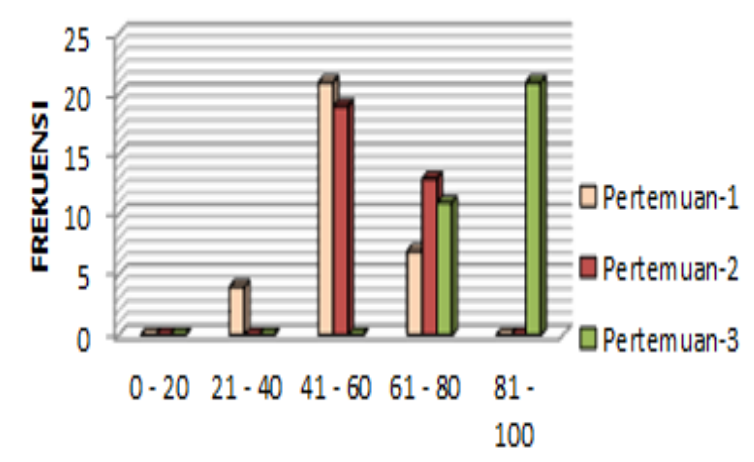

NILAI

Gambar 4. Diagram batang hasil belajar psikomotorik siswa kelas eksperimen

Berdasarkan Gambar 4 dapat dilihat bahwa terjadi perubahan pada hasil belajar psikomotorik siswa. Perubahan tersebut sebagai hasil belajar diperoleh selama menerima pelajaran dengan model pembelajaran Inkuiri.

Hasil belajar psikomotorik siswa di kelas kontrol juga dapat dilihat pada diagram batang pada gambar 5 .

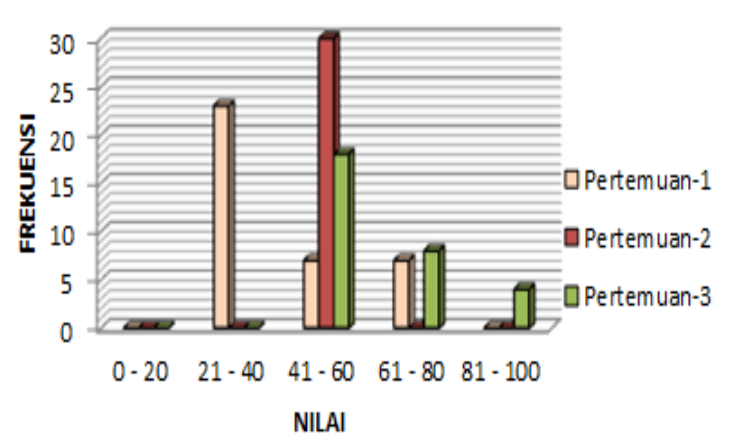

Gambar 5. Diagram batang hasil belajar psikomotorik siswa kelas kontrol 
Berdasarkan Gambar 5, dapat dilihat bahwa terjadi perubahan pada hasil belajar psikomotorik siswa. Perubahan tersebut sebagai hasil belajar diperoleh selama menerima pelajaran dengan pembelajaran Konvensional.

\section{Postes}

Berdasarkan hasil tes yang telah dilakukan di SMA Swasta Harapan Bangsa Kuala diperoleh data mengenai hasil belajar siswa untuk kelas eksperimen dan kelas kontrol. Adapun data hasil belajar postes kelas kontrol dan eksperimen dapat dilihat pada gambar 6 di bawah ini :

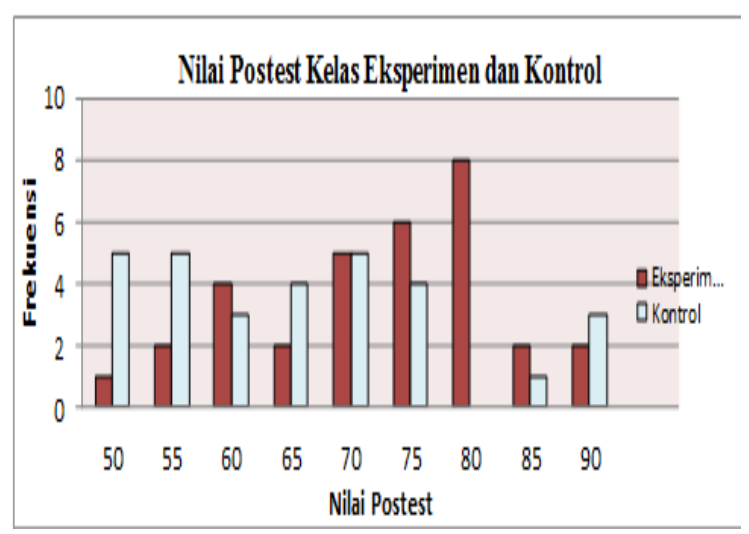

Gambar 6. Diagram Batang Nilai Postes Kelas Eksperimen dan Kelas Kontrol

Dalam penelitian ini menggunakan uji beda (uji t). Setelah diberikan perlakuan, yaitu pada kelas eksperimen dan kelas kontrol, diperoleh hasil postes pada kelas eksperimen dengan nilai rata-rata 72,5 dan hasil postes pada kelas kontrol dengan nilai rata-rata 65,67 . Ringkasan perhitungan uji hipotesis kelas eksperimen dan kelas kontrol seperti Tabel 5.
Tabel 5. Ringkasan Perhitungan Uji Hipotesis

\begin{tabular}{|l|c|c|c|l|}
\hline \multicolumn{1}{|c|}{ Data Kelas } & $\begin{array}{c}\text { Nillai } \\
\text { Rata }- \text { rata }\end{array}$ & $t_{\text {hitung }}$ & $t_{\text {tabel }}$ & Kesimpulan \\
\hline Postes Eksperimen & 72,5 & \multirow{2}{*}{8,65} & 1,67 & Terima $\mathrm{H}_{\mathrm{a}}$ \\
\hline Postes Kontrol & 65,67 & & & \\
\hline
\end{tabular}

Berdasarkan Tabel 5, hasil perhitungan uji perbedaan nilai ratarata postes kelas eksperimen dan kelas kontrol diperoleh $t_{\text {hitung }}=8,65>$ $\mathrm{t}_{\text {tabel }}=1,67$, maka $\mathrm{H} 0$ ditolak dan terima Ha, sehingga diperoleh kesimpulan bahwa terdapat ada pengaruh model pembelajaran inkuiri terhadap hasil belajar siswa pada materi pokok Gerak Lurus di kelas X SMA Swasta Harapan Bangsa T.P 2014/2015

\section{Pembahasan}

Hasil

penelitian

menunujukkan bahwa terdapat pengaruh model pembelajaran Inkuiri terhadap hasil belajar siswa di kelas X SMA Swasta Harapan Bangsa Kuala. Hal ini ditunjukkan dengan perolehan nilai rata-rata postes sebesar 72,5 sedangkan di kelas kontrol nilai rata-rata postes sebesar 65,67 .

Hasil belajar di kelas eksperimen memiliki nilai yang lebih tinggi dibandingkan kelas kontrol karena jika dilihat dari segi proses pembelajaran, Inkuiri memiliki kelebihan. Sebagaimana yang dipaparkan dalam bukunya (Trianto, 2011:168), bahwa inkuiri tidak hanya mengembangkan kemampuan intelektual tetapi seluruh potensi yang ada, termasuk pengembangan emosional dan keterampilan inkuiri merupakan suatu proses yang bermula dari merumuskan masalah, 
merumuskan

hipotesis, mengumpulkan data, menganalisis data, dan membuat kesimpulan.

Hasil penelitian juga menunjukkan bahwa hasil belajar siswa di bidang afektif lebih baik hasilnya di kelas eksperimen dibandingkan kelas kontrol. Hal ini ditunjukkan dengan perolehan jumlah skor atau nilai rata-rata di kelas eksperimen sebesar 74,87. Sedangkan di kelas kontrol dengan nilai rata-rata sebesar 65,97 yang mana nilai sikap dari masing-masing kelas berkategori tinggi.

Afektif belajar siswa yang kategorinya lebih baik di kelas eksperimen daripada kontrol sudah jelas karena pada saat proses pembelajaran berlangsung di kelas eksperimen para siswa merasa tertantang karena dituntut untuk berpikir kritis sehingga pikiran mereka menyatu dengan suasana kelas dan tidak merasa bosan para siswa lebih bersemangat.

Hasil belajar siswa pada aspek psikomotor di kelas eksperimen memperoleh hasil yang baik. Hal ini dilihat dari skor nilai pertemuan awal hingga akhir selalu mengalami peningkatan. Skor nilai pada pertemuan I sebesar 52,99 dengan kategori sedang. Kemudian pada pertemuan II meningkat menjadi 62,75 dengan kategori tinggi, dan pertemuan III meningkat lagi menjadi 82,04 dengan kategori sangat tinggi. Menurut peneliti, pada awal pelaksanaan model pembelajaran inkuiri, para siswa masih banyak yang bingung dengan instruksi yang diberikan karena belum terbiasa dengan model tersebut sehingga keterampilan mereka belum sepenuhnya terlihat. Akan tetapi pada pertemuan berikutnya sudah mulai tampak kemampuan dari para siswa hingga pada pertemuan akhir tingkat keterampilan mereka sudah bisa dikatakan berkategori baik.

Hasil belajar siswa pada aspek keterampilan di kelas kontrol juga mengalami peningkatan. Hal ini dilihat dari skor pertemuan awal hingga selalu meningkat. Seperti yang terlihat pada diagram batang, skor pada pertemuan I sebesar 37,70 dengan kategori kurang. Kemudian pada pertemuan II meningkat menjadi 47,80 dengan kategori sedang, dan pertemuan III meningkat lagi menjadi 49,26 dengan kategori sedang. Dalam hal kelas eksperimen masih lebih unggul dibanding kelas kontrol pada hasil belajar siswa di bidang keterampilan.

Model pembelajaran Inkuiri memberikan banyak kelebihan, yaitu: 1) Pada langkah mengidentifikasi pertanyaan, siswa dibawa ke dalam satu permasalahan sebagai dasar untuk mencuri daya tarik siswa dalam mengikuti pelajaran dan membuat mereka semakin penasaran dengan pertanyaan tersebut. 2) pada langkah membuat hipotesis, siswa diberikan kesempatan untuk menuangkan isi pikiran dengan cara memberikan jawaban sementara atas pertanyaan tadi. Dari beberapa jawaban yang dilontarkan siswa, bisa dilihat bagaimana cara mereka bersikap seperti menghargai pendapat orang lain, rasa percaya diri mereka dalam mengutarakan pendapat, dan lain-lain. 3) pada langkah mengumpulkan dan menganalisis data, siswa diberikan kesempatan untuk menguji hipotesis dengan melakukan percobaan untuk memperoleh bukti dengan data yang didapat. Dari kegiatan ini, peneliti bisa melihat bagaimana keterampilan 
siswa dalam mengamati percobaan, menanyakan hal yang menyangkut percobaan dan pengolahan data. Selain itu sikap siswa juga banyak yang harus diamati dari kegiatan ini, seperti sikap gotong royong, disiplin, jujur dan sebagainya. 4) pada langkah menilai hipotesis dan membuat generalisasi, guru memandu diskusi tentang hasil dan sejauh mana hasil-hasil itu mendukung hipotesis. Juga, murid melakukan generalisasi terhadap hasil berdasarkan asesmen terhadap hipotesis.

Dari beberapa pernyataan di atas jelaslah bahwa model pembelajaran inkuiri dapat meningkatkan hasil belajar siswa dan tentunya model pembelajaran Inkuiri lebih baik dibandingkan pembelajaran Konvensional. Sesuai juga dengan apa yang dikatakan oleh Suchman (dalam Sani, 2013) bahwa model pembelajaran inkuri membantu peserta didik belajar merumuskan dan menguji pendapatnya sendiri serta memiliki kesadaran akan kemampuannya. Selain itu, sesuai juga dengan pernyataan Nur (dalam Trianto) pada teori belajar kognitif yang mengatakan bahwa pengetahuan dating dari tindakan. Piaget yakin bahwa pengalaman-pengalaman fisik dan manipulasi lingkungan penting bagi terjadinya perubahan perkembangan. Sementara itu bahwa interaksi sosial dengan teman sebaya, khususnya berargumentasi dan berdiskusi membantu memperjelas pemikiran yang pada akhirnya memuat pemikiran itu menjadi lebih logis.

Jika banyak teori yang mendukung model Pembelajaran Inkuiri, lain halnya dengan pembelajaran Konvensional yang mana proses pembelajaran diserahkan sepenuhnya pada guru sebagai penyampai informasi. Dalam melaksanakan perannya, sering guru menggunakan metode ceramah sebagai metode utama. Sedangkan pada model Inkuiri, dalam proses pembelajaran mengikuti sintak atau fase inkuiri yang mana dalam menjalankannya siswa lebih mengambil peran.

Selang kenaikan nilai yang paling tinggi antara kelas yang menggunakan model inkuiri dengan kelas konvensional adalah pada penelitian Purwanto (2012) dengan judul penelitian 'Kemampuan Berpikir Logis Siswa SMA Negeri 8 Kota Bengkulu dengan Menerapkan Model Inkuiri Terbimbing dalam Pembelajaran Fisika" dengan kenaikan nilai rata-rata hasil belajar siswa adalah 4,41 dengan nilai postes pada kelas eksperimen adalah 72,37 sedangkan pada kelas konvensional dengan nilai 67,96. Kemudian, untuk hasil kenaikan hasil belajar yang dihasilkan oleh peneliti sendiri adalah sebesar 6,83 dengan nilai postes pada kelas eksperimen adalah sebesar 72,5 dan kelas kontrol 65,67. Dalam hal ini terlihat bahwa model pembelajaran inkuiri yang peneliti gunakan lebih tinggi rentan kenaikan nilainya dibandingkan dengan peneliti terdahulu yang dikutip oleh peneliti.

Walaupun penggunaan model pembelajaran inkuiri dapat meningkatkan hasil belajar siswa, tetapi selama pembelajaran masih ada kendala yang dihadapi, yaitu pada diskusi kelompok terdapat beberapa orang siswa yang bermainmain atau kurang berpartisipasi dalam menyelesaikan tugas kelompok 
dan praktikum sehingga menganggu konsentrasi siswa lain sehingga hasil yang didapatkan tidak efektif dan efisien. Pengaturan waktu dalam RPP, dalam pelaksanaannya peneliti masih menemukan kekurangan waktu selama proses pembelajaran, hal ini terjadi karena dalam kegiatan pengolahan data serta membuat kesimpulan dari percobaan yang dilakukan memang memerlukan waktu yang lama.

\section{KESIMPULAN DAN SARAN}

Kesimpulan

Dari hasil analisis data yang dilakukan dapat ditarik kesimpulan (1) Hasil belajar siswa pada aspek kognitif dengan model pembelajaran inkuiri diperoleh nilai pretes sebesar 27,97 dan setelah nilai postes siswa sebesar 72,5 sedangkan hasil belajar siswa pada pembelajaran konvensional diperoleh nilai pretes sebesar 29,83 dan nilai postes siswa sebesar 65,67. (2) Hasil belajar afektif siswa selama mengikuti pembelajaran dengan menggunakan model pembelajaran inkuiri mencapai 74,87 dengan kategori baik, sedangkan pada pembelajaran konvensional mencapai 65,97 dengan kategori baik. Hasil belajar psikomotorik dengan menggunakan model inkuiri mencapai 64,58 dengan kategori baik. Sedangkan pada pembelajaran konvensional mencapai 49,26 dengan kategori cukup. (3) Ada pengaruh model pembelajaran inkuiri terhadap hasil belajar siswa pada materi pokok Gerak Lurus di kelas X SMA Swasta Harapan Bangsa Kuala T.P 2014/2015.

\section{Saran}

Berdasarkan hasil penelitian dan kesimpulan di atas, maka sebagai tindak lanjut dari penelitian ini disarankan beberapa hal sebagai berikut: (1) Model pembelajaran inkuiri dapat digunakan sebagai salah satu alternatif model pembelajaran dalam upaya meningkatkan hasil belajar siswa yaitu pada aspek kognitif, sikap dan keterampilan. (2) Untuk mendapat hasil penelitian yang lebih baik, sebaiknya sebelum melakukan penelitian, pada kelas yang akan menggunakan model inkuiri dilakukan pembiasaan menggunakan model nkuiri terlebih dahulu.

\section{DAFTAR PUSTAKA}

Arikunto, S., (2010), Prosedur Penelitian, Penerbit PT Rineka Cipta, Jakarta.

Eggen dan Kauchak. (2012). Strategi dan Model Pembelajaran Mengajarkan Konten dan Keterampilan Berpikir. Indeks. Jakarta Barat

Purwanto, A. (2012). Kemampuan Berpikir Logis Siswa SMA Negeri 8 Kota Bengkulu dengan Menerapkan Model Inkuiri Terbimbing dalam Pembelajaran Fisika. Jurnal Exacta 10: 133-135.

Sani, R., A. (2013). Inovasi Pembelajaran. Bumi Aksara, Jakarta.

Sudjana. (2005). Metode Statistika. Tarsito, Bandung.

Trianto. (2011). Mendesain ModelModel Pembelajaran InovatifProgresifs. Kencana, Jakarta. 